\title{
FAKTOR YANG MEMPENGARUHI PELAKSANAAN SASARAN KESELAMATAN PASIEN SEBAGAI SALAH SATU INDIKATOR PELAYANAN DI RUMAH SAKIT
}

\author{
Elisa Claudia Simanjuntak / 181101114 \\ elclaudia02@gmail.com
}

\begin{abstract}
ABSTRAK
Latar Belakang : Keselamatan pasien adalah suatu sistem atau proses di rumah sakit yang dilakukan untuk memberikan rasa aman pada pasien selama di rumah sakit. Dalam pelaksanaan keselamatan pasien, ada sasaran yang harus dicapai.

Tujuan : Tujuan penulisan kajian ini adalah untuk mengetahui faktor yang mempengaruhi pelaksanaan sasaran keselamatan pasien di rumah sakit.

Metode : Metode yang digunakan dalam kajian ini adalah literature review, yaitu dengan cara menganalisis, mengeksplorasi serta mengkaji bebas jurnal dan buku teks yang membahas tentang faktor-fakor yang mempengaruhi penerapan sasaran keselamatan pasien di rumah sakit Hasil : Terdapat tiga faktor yang mempengaruhi tercapainya sasaran keselamatan pasien, yaitu tingkat pengetahuan perawat, sikap perawat, dan fasilitas di rumah sakit.

Pembahasan : Sasaran keselamatan pasien menurut PERMENKES No. 1691 Tahun 2011 Pasal 8 ada enam, yaitu ketepatan identifikasi pasien, peningkatan komunikasi yang efektif, peningkatan keamanan obat yang perlu diwaspadai, kepastian tepat lokasi;prosedur;pasien, pengurangan resiko infeksi terkait pelayanan kesehatan, serta pengurangan resiko pasien jatuh. Dalam penerapan sasaran keselamatan pasien, faktor-faktor yang mempengaruhi ada tiga.

Kata Kunci : Sasaran Keselamatan Pasien, Rumah Sakit, Indikator Pelayanan.
\end{abstract}




\section{Latar Belakang}

Rumah sakit sebagai salah satu institusi pelayanan kesehatan memiliki fungsi penting dalam meningkatkan derajat kesehatan masyarakat sehingga dituntut untuk selalu meningkatkan mutu pelayanan yang diberikan. Mutu pelayanan dapat dikatakan baik apabila rumah sakit dapat memberikan pelayanan yang bermutu dengan memperhatikan segala aspek.

Salah satu aspek yang menunjukan bahwa pelayanan di rumah sakit bermutu adalah keselamatan pasien. Selama proses perawatan pasien, keselamatan penting diperhatikan. Hal ini akan memberikan rasa aman kepada pasien selama di rumah sakit. Oleh karena itu, rumah sakit dan tenaga kesehatan wajib melaksanakannya.

Dalam menjalankan keselamatan pasien, ada sasaran yang harus dicapai. Namun, dalam proses pencapaiannya ada faktor-faktor yang mempengaruhi, antara lain tingkat pengetahuan perawat, sikap perawat, serta fasilitas rumah sakit.

\section{Tujuan}

Untuk mengetahui faktor yang mempengaruhi pelaksanaan sasaran keselamatan pasien di rumah sakit.

\section{Metode}

Metode yang digunakan dalam kajian ini adalah literature review, yaitu dengan cara menganalisis, mengeksplorasi serta mengkaji bebas jurnal dan buku teks yang membahas tentang faktor-fakor yang mempengaruhi penerapan sasaran keselamatan pasien di rumah sakit. Referensi berupa jurnal dan buku teks yang digunakan adalah sebanyak 14 . Jurnal yang digunakan sebagai referensi dalam tulisan ini diterbitkan dalam kurun waktu 10 tahun terakhir.

\section{Hasil}

Hasil pengkajian menunjukan bahwa terdapat tiga faktor yang mempengaruhi tercapainya sasaran keselamatan pasien. Faktor-faktor tersebut adalah tingkat pengetahuan perawat, sikap perawat, dan fasilitas di rumah sakit.

\section{Pembahasan}

Tujuan dari sasaran keselamatan pasien adalah mendorong peningkatan spesifik dalam keselamatan pasien. Sasaran keselamatan pasien yang dimaksud dalam PERMENKES No. 1691 Tahun 2011 Pasal 8, meliputi ketepatan identifikasi pasien, peningkatan komunikasi yang efektif, 
peningkatan keamanan obat yang perlu diwaspadai, kepastian tepat lokasi;prosedur;pasien, pengurangan resiko infeksi terkait pelayanan kesehatan, serta pengurangan resiko pasien jatuh.

Dalam proses mencapai sasaran tersebut, ada beberapa faktor yang mempengaruhi. Faktor-faktor yang mempengaruhi tercapainya sasaran keselamatan pasien adalah:

1. Tingkat pengetahuan perawat

Pengetahuan sangat penting khususnya dalam pengambilan keputusan. Tenaga kesehatan dengan pengetahuan yang baik, akan membuat lebih banyak pertimbangan sebelum bertindak sesuai dengan ilmu yang dimilikinya.

2. Sikap perawat

Sikap dapat diartikan sebagai kesiapan atau kesediaan dalam bertindak. Apabila sikap perawat dalam bertindak menerapkan sasaran keselamatan pasien acuh tak acuh, maka dapat disimpulkan bahwa sasaran tidak akan dapat tercapai.

3. Fasilitas rumah sakit

Apabila tingkat pengetahuan dan sikap perawat sudah baik, namun apabila tidak didukung oleh fasilitas sama dengan nol.
Oleh sebab itu, tingkat pengetahuan, sikap perawat, serta fasilitas rumah sakit harus baik atau seimbang.

\section{Penutup}

Sasaran keselamatan pasien menurut PERMENKES No. 1691 Tahun 2011 Pasal 8 ada enam, yaitu ketepatan identifikasi pasien, peningkatan komunikasi yang efektif, peningkatan keamanan obat yang perlu diwaspadai, kepastian tepat lokasi;prosedur;pasien, pengurangan resiko infeksi terkait pelayanan kesehatan, serta pengurangan resiko pasien jatuh. Dalam penerapan sasaran tersebut, beberapa faktor yang mempengaruhi adalah tingkat pengetahuan perawat, sikap perawat, serta fasilitas rumah sakit.

\section{Referensi}

Darliana, D. (2016). Hubungan Pengetahuan Perawat dengan Upaya Penerapan Patient Safety di Ruang Rawat Inap RSUD Dr. Zainoel Abidin Banda Aceh. Idea Nursing Journal. 7(1): 62-63.

Firawati. (2012). Pelaksanaan Program Keselamatan Pasien di RSUD Solok. 
Jurnal Kesehatan Masyarakat. 6(2): 7477.

Ismainar, Hetty. (2015). Keselmatan

Pasien di Rumah Sakit. Yogyakarta:

Deepublish.

Kemenkes RI. (2011). Peraturan

Menteri Kesehatan Republik Indonesia Nomor1691/MENKES/PER/VIII/2011 tentang Keselamatan Pasien Rumah Sakit. Jakarta: Depkes RI.

Neri, Reno A., dkk. (2018). Analisis Pelaksanaan Sasaran Keselamatan Pasien di Rawat Inap Rumah Sakit Umum Daerah Padang Pariaman. Jurnal Kesehatan Andalas. 7(4): 48-55.

Pambudi, Yohanes, dkk. (2018). Faktor-Faktor Yang Mempengaruhi Perawat Dalam Penerapan 6 SKP (Sasaran Keselamatan Pasien) Pada Akreditasi JCI (Joint Commission International)di Ruang Rawat Inap Rumah Sakit Panti Waluya Malang. Nursing News. 3(1): 729-747.

Rivai, F. \& Sidin, A.I. (2016). Faktor Yang berhubungan dengan implementasi keselamatan pasien di RSUD Ajjapponnge Soppeng Tahun
2015. Jurnal Kebijakan Kesehatan Indonesia. (5):152-157.

Setiyani, M. D. (2016). Implementasi Sasaran Keselamatan Pasien Di Ruang Rawat Inap RSU Kabupaten Tangerang. JKFT, (2): 59-69.

Simamora, R. H. (2019). Documentation of Patient Identification into the Electronic System to Improve the Quality of Nursing Services. International Journal of Scientific \& Technology Research.

Simamora, R. H. (2019). The infiuence of Training Handover Based SBAR Communication for Improving Patients Safety. Indian Journal of Public Health Research \& Development.

Tutiani. (2017). Manajemen Keselamatan Pasien. Jakarta.

Utarini, A. \& Djasri, H. (2012). Keselamatan Pasien dan Mutu Pelayanan Kesehatan. Jurnal Manajemen Pelayanan Kesehatan. 159160.

Yulidar, E. \& Nasution, A. (2019). Analisi Faktor-Faktor yang 
Mempengaruhi Perilaku Perawat

Dalam Rangka Penerapan Patient

Safety di Rawat Inap RS. Royal Prima

Jambi Tahun 2018. Scientia Journal.

8(1): 370-371. 